\title{
THE POPULATION CYTOGENETICS OF CREPIS CAPILLARIS I. CHIASMA VARIATION
}

\author{
C. WHITEHOUSE*, L. A. EDGAR†, G. H. JONES*, AND J. S. PARKER † \\ * Department of Genetics, University of Birmingham, Birmingham B15 2TT, England; \\ $\dagger$ Department of Microbiology and Plant Biology, Queen Mary College, University of \\ London, Mile End Road, London E1 4NS, England.
}

Received 9.xii.80

\section{SUMMARY}

\begin{abstract}
Chiasma variation has been studied in material from 9 different natural populations of Crepis capillaris. Significant differences in mean cell chiasma frequency were found between populations, between families within populations and also between plants within families. An analysis of chiasma distribution among 11 regions spread over the 3 chromosome pairs revealed an underlying tendency for chiasmata to occupy characteristic positions in bivalents. However, this is a quantitative rather than qualitative effect and marked variation in chiasma position distributions were evident at population, family and individual plant levels. The findings of this survey are discussed in relation to the significance and role of genetical recombination in natural populations.
\end{abstract}

\section{INTRODUCTION}

EXPERIMENTAL studies have answered many fundamental questions concerning the mechanism and control of chiasma formation, but very much less is known about the extent and significance of chiasma variation in natural populations. Renewed interest in the adaptive role and evolutionary advantages of recombination (e.g., Maynard-Smith, 1977) have recently drawn attention to this deficiency. Although interspecific variations in chiasma frequency and distribution have been extensively studied (John and Lewis, 1965), relatively few studies have systematically investigated the chiasma variation occurring between and within natural populations of particular species.

The present study is part of a wide survey of cytogentical variations in natural populations of the widely distributed plant species Crepis capillaris (Compositae), and deals with the chiasma variation observed between and within the natural populations studied.

\section{MATERIALS AND METHODS}

\section{(i) Sampling from natural populations}

Ripe seed (achenes) were collected separately from 12-17 plants from each population sampled during the summer of 1976 (table 1). Families, each consisting of two plants were raised from the seed samples obtained from each individual parent plant; thus a family represents the common seed progeny of a single natural population parent plant and the members of a family are either half-sibs or full-sibs, since Crepis capillaris is an outbreeding species. Family size was restricted to two plants in order to minimise the labour of cytological scoring, yet providing a valid test of 
TABLE 1

Locations and descriptions of the 9 natural populations of Crepis capillaris included in this study

\begin{tabular}{|c|c|c|c|c|}
\hline Code & Location & Grid ref. & Altitude (m) & Habitat \\
\hline $\mathrm{BH}$ & $\begin{array}{l}\text { Bredon Hill, } \\
\text { Worcestershire }\end{array}$ & 973408 & 143 & Sheep pasture \\
\hline BR & $\begin{array}{l}\text { Bromsgrove, } \\
\text { Worcestershire }\end{array}$ & 961701 & 83 & Hedgerow \\
\hline DR & $\begin{array}{l}\text { Driffield, } \\
\text { Gloucestershire }\end{array}$ & 407119 & 97 & Weedy lawn \\
\hline EB & East Bridge, Suffolk & 645266 & 5 & Road verge \\
\hline ED & $\begin{array}{l}\text { Edgbaston, } \\
\text { West Midlands }\end{array}$ & 045837 & 145 & Waste ground \\
\hline EWH & $\begin{array}{l}\text { East Wretham Heath, } \\
\text { Norfolk }\end{array}$ & 571288 & 32 & Grassy heathland \\
\hline IN & Ingham, Lincolnshire & 963833 & 65 & Field margin \\
\hline PM & Porthmadog, Gwynedd & 562371 & 10 & Coastal dunes \\
\hline SJT & $\begin{array}{l}\text { St. Jean Trolimon, } \\
\text { Finistére, France. }\end{array}$ & $4^{\circ} 21^{\prime} \mathrm{W} 47^{\circ} 51^{\prime} \mathrm{N}$ & 44 & Field margin \\
\hline
\end{tabular}

between-family within-population chiasma variation. Progeny plants were grown in a randomised design at Queen Mary College Field Station, Brentwood, Essex. Young capitula, with florets containing meiotic divisions were collected from the plants as they become available, and fixed in Carnoy's $(6: 3: 1)$ fixative.

\section{(ii) Cytological technique and scoring procedure}

Chiasmata were scored from 40 lacto-propionic orcein stained squash preparations of pollen mother cells (p.m.c.) per plant, at metaphase I of meiosis. The three chromosomes of the haploid complement of Crepis capillaris (fig. 1), designated A, D and C (Navashin, 1925), are easily identifiable at mitosis and meiosis by their different length and centromere position (Tease and Jones, 1976). These features of chromosome organisation, combined with the co-orientation of centromeres at Metaphase I, permit each bivalent at meiosis to be subdivided into eleven distinct regions of approximately equal length for the purpose of locating chiasmata, as shown in fig. 2.

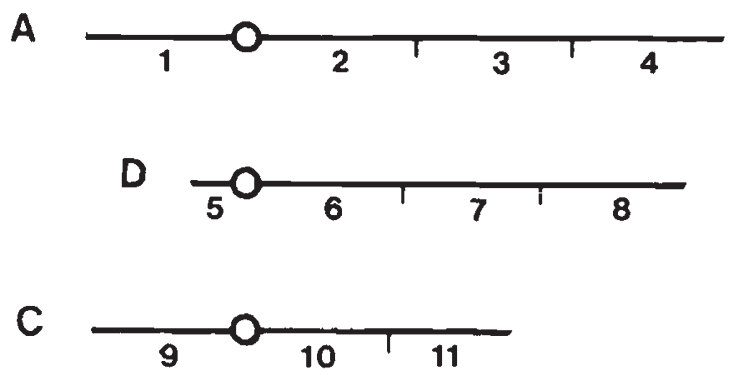

Frg. 2.-Diagrammatic representation of the Crepis cappillaris karyotype showing the subdivision into regions adopted for defining chiasma locations. 


\section{Plate I}
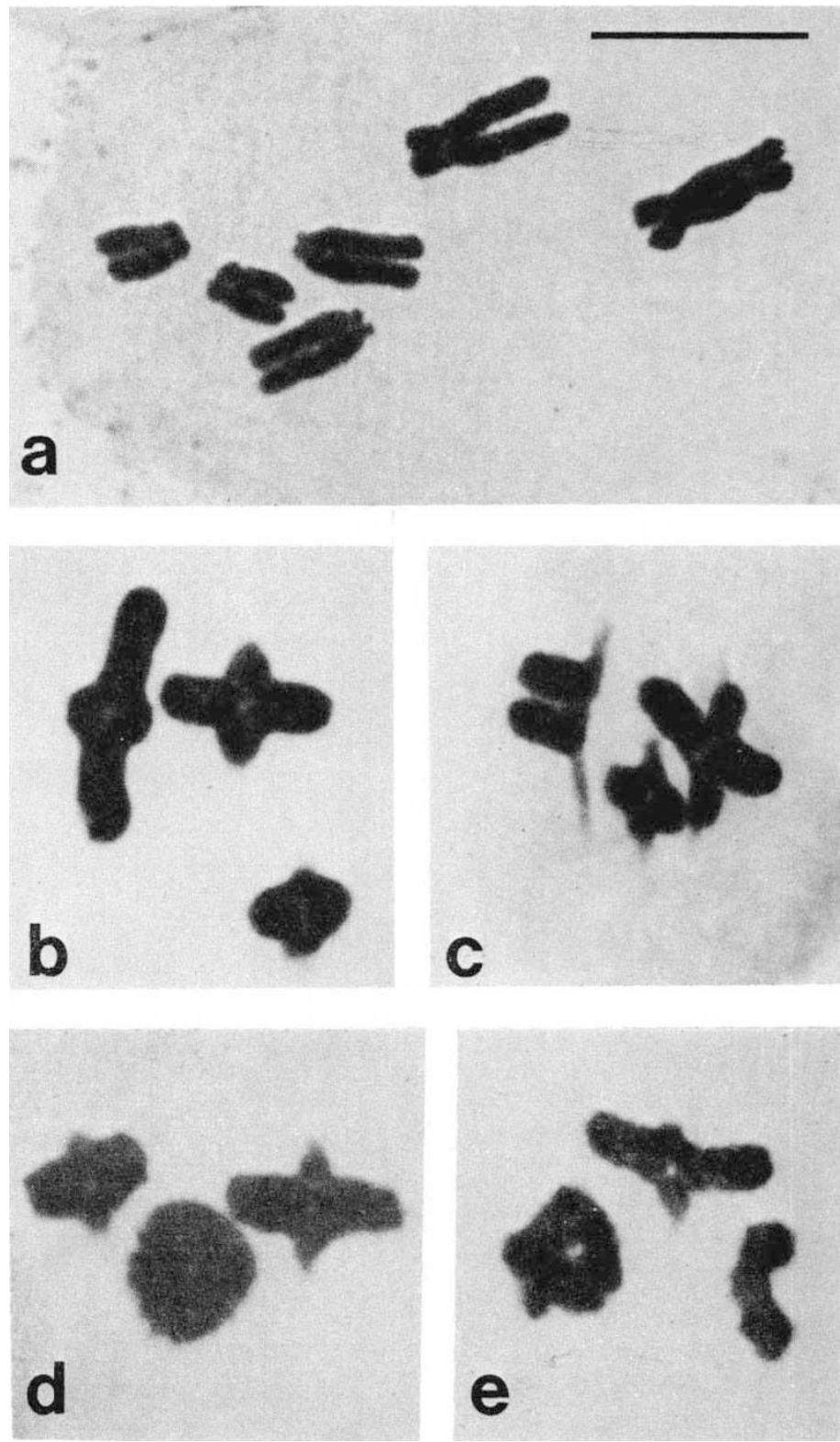

Fig. 1.-a.-c. The chromosomes of Crepis capillaris at mitotic metaphase (fig. 1a) and meiotic metaphase I (figs. 1b-e). b. 3 chiasmata located at regions $A_{3}, D_{6}, C_{10}$ (see fig. 2). c. 3 chiasmata located at regions $A_{2}, D_{5}, C_{10}$. d. 4 chiasmata located at regions $A_{1}, A_{4}, D_{6}$, $C_{10}$. e. 4 chiasmata located at regions $A_{1}, A_{3}, D_{6}, C_{9}$. Bar represents $10 \mu \mathrm{m}$. 


\section{Results}

\section{(i) Procedural problems}

By growing plants from different populations in one randomised experiment under uniform conditions possible environmental effects on chiasmata were minimised but the possibility of genotype $\times$ environment interactions remained (Zarchi et al., 1972). In order to investigate this possibility, plants from the ED population of Crepis capillaris grown in experimental conditions were compared to plants of the same population growing in their native habitat; their mean chiasma frequencies were found to be very similar ( 3.88 and 3.80 respectively) and not significantly different $\left(t_{(38)}=\right.$ $1 \cdot 02 ; \mathrm{P}>0 \cdot 30)$.

The question of possible effects on chiasma frequency due to differences in fixation date has been thoroughly studied by Tease (1977) who showed that chromosomes and regions behaved consistently as regards chiasma formation over the five sampling dates studied.

Chiasmata were scored at metaphae I; two different approaches indicate that chiasma terminalisation does not occur in Crepis capillaris and that metaphase I scores are therefore an accurate means of measuring crossingover. There is no detectable change in chiasma frequency or distribution between diakinesis, the earliest stage at which chiasmata can be reliably scored in this species, and metaphase I. Furthermore, good agreement was obtained between crossover frequency in the long arm of the $\mathrm{C}$ chromosome carrying a paracentric inversion, estimated directly using the method of Brandham (1969), and chiasma frequency scored at metaphase I.

\section{(ii) The analysis of chiasma variation}

Chiasma locations were recorded by noting the presence or absence of chiasmata in each of the 11 recognisable regions (See Materials and Methods) in each of 40 p.m.c. per plant. The total chiasma scores of each plant of a representative population (ED) are given in table 2, to illustrate the general form of the data used in the analysis of variance presented below. Table 3 summarises the mean cell chiasma frequencies of all the plants and populations included in the survey.

A two-way hierarchical (nested) analysis of variance was performed on the chiasma data. For this purpose, populations were restricted to ten families of two plants each, in order to maintain orthogonality and facilitate the analysis. Divergent plants such as translocation heterozygotes and homozygotes, and triploids, which occurred rather infrequently, were excluded, as were the somewhat more frequent B-chromosome plants which showed chiasma frequency effects due to the presence of B-chromosomes. Where a further reduction in family number was necessary, this was achieved by random selection. Three populations had one or more missing plants when this exercise was completed (five missing plants in all). These gaps were filled by substituting mean values for each chromosome region, derived from other plants of the population concerned and the degrees of freedom were correspondingly adjusted (Snedecor and Cochran, 1967). Before carrying out the analysis, each item of data (chiasmata per region per plant, summed over 40 cells) was expressed as a percentage and transformed to angles. The experimental design allows a theoretical error 

$\stackrel{\ominus}{\longrightarrow}$

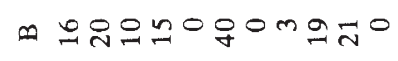

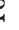

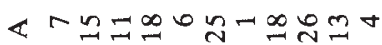

$$
\begin{aligned}
& \text { m }
\end{aligned}
$$

a

$$
\text { 《IปIก๊ m }
$$

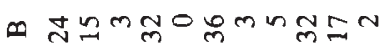

$\infty$

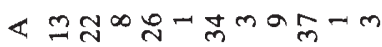

$m \stackrel{\infty}{=}=\infty$ 岀

N

《윰ำ

6

D 으

(1)

《

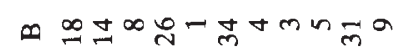

n

«

๓

$\checkmark$

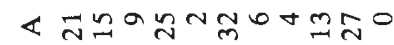

$\infty$ प্స

m

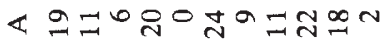

๓

N

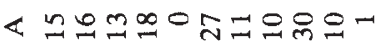

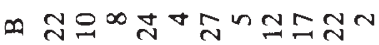

$\sim$

<ลำ을

Hentmon a

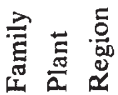

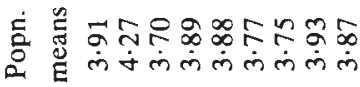

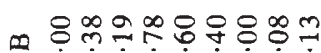
우

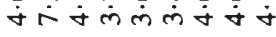

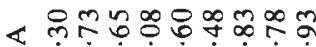
$\dot{\forall} \dot{\forall} \dot{m} \dot{\forall} \dot{m} \dot{m} \dot{n} \dot{n} \dot{m}$

๓ a

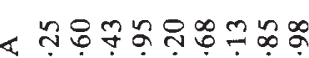
$\dot{n} \dot{m} \dot{m} \dot{m} \dot{\text { m }} \dot{m} \dot{\mathrm{j}} \dot{m}$

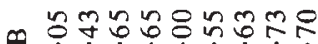
$\infty$

$\dot{\forall} \dot{m} \dot{n} \dot{n} \dot{\sigma} \dot{m} \dot{m} \dot{n} \dot{n}$

« nூ $\dot{m} \dot{m} \dot{m} \dot{m} \dot{m} \dot{m} \dot{m} \dot{\text { d }}$

ก $\dot{n} \dot{\sim} \dot{m} \dot{m} \dot{m} \dot{m} \dot{m}$

$N$

« $\dot{n} \dot{\nabla} \dot{\nabla} \dot{m} \dot{m} \dot{m} \dot{m} \dot{m}$

๓ ํํํำตำำำ

$\infty$

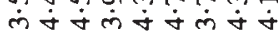

< Б웅

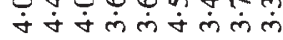

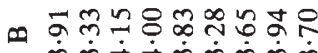
$\dot{n} \dot{n} \dot{\sigma} \dot{\sigma} \dot{m} \dot{n} \dot{m} \dot{m}$

n $m \infty n \infty m \infty \infty$ 에

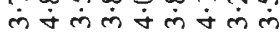

๓

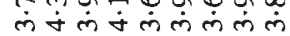

$\nabla$

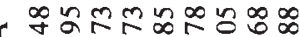
$\dot{m} \dot{m} \dot{m} \dot{m} \dot{m} \dot{m} \dot{\sim} \dot{m} \dot{m}$

๓ 유ำ $\dot{m} \dot{\nabla} \dot{m} \dot{m} \dot{\nabla} \dot{m} \dot{m} \dot{m}$ m

< $\dot{\forall} \dot{n} \dot{m} \dot{m} \dot{m} \dot{\nabla} \dot{m} \dot{n}$

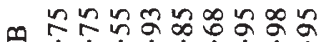
म $\dot{m} \dot{m} \dot{m} \dot{m} \dot{m} \dot{m} \dot{m}$ < ํํำㅇำ

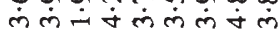

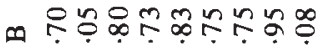

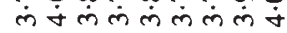
$-$ « $\dot{n} \dot{n} \dot{m} \dot{m} \dot{\text { व }} \dot{n} \dot{n}$

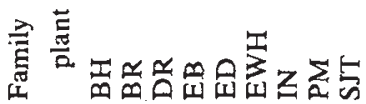


item $(820 \cdot 7 / n)$ to be used in the analysis of variance (Fisher and Yates, 1963; Snedecor and Cochran, 1967).

This natural population material displays a striking amount of chiasma variation. The mean cell chiasma frequencies of individual plants vary between $7 \cdot 38$ (BRIOB) and $3 \cdot 13$ (IN9A) among plants showing a normal meiotic phenotype, but falling as low as 1.93 in a single partially desynaptic plant (DR2A). The analysis of variance (table 4) reveals significant chiasma

TABLE 4

Analysis of variance of chiasma frequencies in natural populations of Crepis capillaris

\begin{tabular}{|c|c|c|c|c|c|}
\hline Item & SS & $\mathbf{N}$ & MS & $\mathrm{F}$ & $\mathrm{P}$ \\
\hline Populations (P) & $2420 \cdot 283$ & 8 & $302 \cdot 530$ & $2 \cdot 510$ & $<0.05$ \\
\hline \multicolumn{6}{|l|}{ Families within } \\
\hline populations (FWP) & $9761 \cdot 508$ & 81 & $120 \cdot 512$ & $1 \cdot 397$ & $<0.05$ \\
\hline \multicolumn{6}{|l|}{ Plants within } \\
\hline families (PWF) & $7330 \cdot 555$ & 85 & $86 \cdot 242$ & $4 \cdot 203$ & $<0.001$ \\
\hline Chromosomes (C) & $47699 \cdot 229$ & 2 & $23849 \cdot 615$ & $325 \cdot 424$ & $<0.001$ \\
\hline \multicolumn{6}{|l|}{ Regions within } \\
\hline chromosomes (RWC) & $581661 \cdot 583$ & 8 & $72707 \cdot 698$ & $326 \cdot 245$ & $<0.001$ \\
\hline $\mathrm{RWC} \times \mathrm{P}$ & $14263 \cdot 163$ & 64 & $222 \cdot 862$ & 1.939 & $<0 \cdot 001$ \\
\hline $\mathrm{C} \times \mathrm{P}$ & $1172 \cdot 247$ & 16 & $73 \cdot 265$ & $2 \cdot 411$ & $<0.01$ \\
\hline $\mathrm{C} \times \mathrm{FWP}$ & $4923 \cdot 726$ & 162 & $30 \cdot 393$ & $1 \cdot 573$ & $<0.001$ \\
\hline RWC $\times$ FWP & $74465 \cdot 235$ & 648 & $114 \cdot 915$ & $1 \cdot 082$ & $<0.001$ \\
\hline $\mathrm{C} \times \mathrm{PWF}$ & $3283 \cdot 880$ & 170 & $19 \cdot 317$ & - & NS \\
\hline $\mathrm{RWC} \times \mathrm{PWF}$ & $72240 \cdot 120$ & 680 & $106 \cdot 235$ & $5 \cdot 178$ & $<0.001$ \\
\hline Error & - & $\infty$ & $20 \cdot 518$ & & \\
\hline
\end{tabular}

frequency differences between populations, between families within populations and also between plants within families. The least dramatic differences occur between populations. All but one of the populations fall within a quite narrow range of mean cell chiasma frequencies, from 3.70 to 3.93 and only one population (BR) is strikingly different from the others with a mean cell chiasma frequency of $4 \cdot 27$. The significant "between families within populations" item implies that, on average, plants belonging to the same families are more alike in their chiasma frequencies than are different families. Nevertheless, there are also numerous clear exceptions to this generalisation, where plants belonging to the same family show very divergent chiasma frequencies and this variation is reflected in the highly significant "between plants within families" item in the analysis of variance.

The analysis of variance also shows that there are highly significant differences in chiasma frequency between the 11 regions of the chromosome complement. This item of the analysis has been subdivided into "between chromosome" and "between regions within chromosome" effects, both of which are highly significant. The first of these subitems confirms earlier reports (Richardson, 1935; Tease, 1977) that the three bivalents of Crepis capillaris show characteristically different mean chiasma frequencies, which are related to chromosome length. Our data on this point are in broad agreement with the findings of Richardson (1935) and Tease (1977) but not with those of Brown and Jones (1976) who reported that the small C bivalent had a mean chiasma frequency exceeding that of the longer $D$ bivalent. The present study also demonstrates clearly that different regions of the three bivalents show a pattern of chiasma localisation such that 

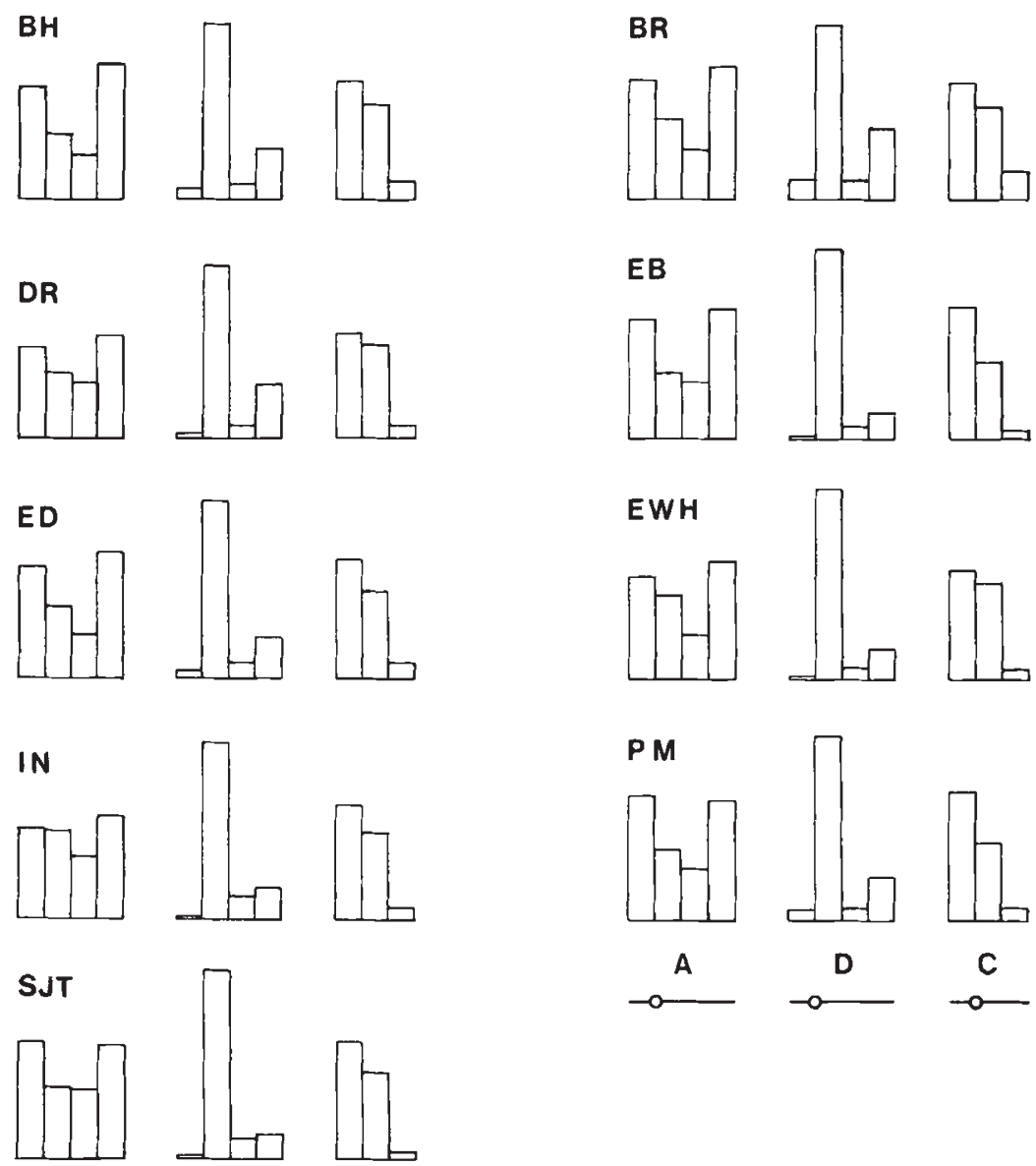

A
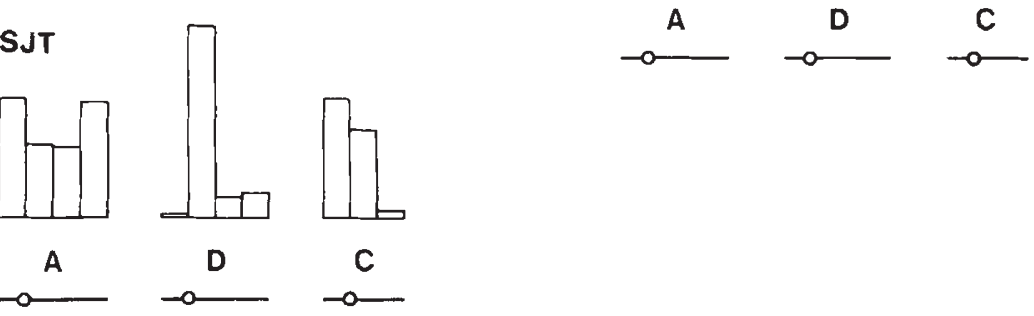

FIG. 3.-Chiasma distribution among 11 bivalent regions of Crepis cappillaris for 9 natural populations.

certain areas are favoured for chiasma formation while others are deficient in chiasmata. The general nature of this localisation pattern is shown in fig. 3 .

However, all the above are average effects which conceal a great deal of variation. The pattern of chiasma distribution between bivalents and between regions within bivalents is not entirely consistent over populations, families or plants within families, as shown by the significance of all the interaction items but one (chromosomes $\times$ plants within families), in the analysis of variance. It is instructive to examine this variation, since it illustrates very forcibly the remarkable chiasma variation shown by this species. Variations in the chiasma distributions of families and of individual plants within families are illustrated by reference to a few selected families from a single population (DR), since it is not practicable to display all the 

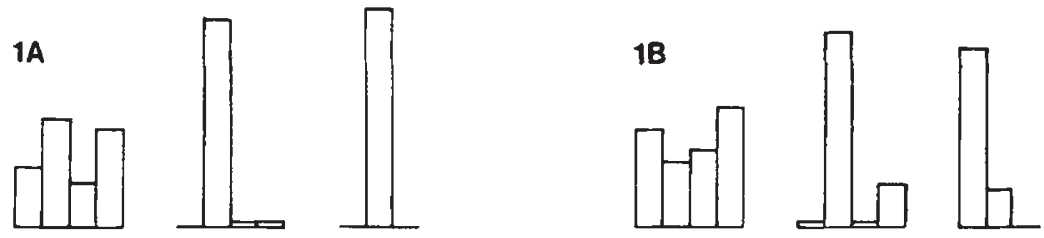

$3 A$
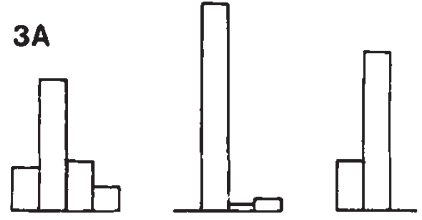

3B
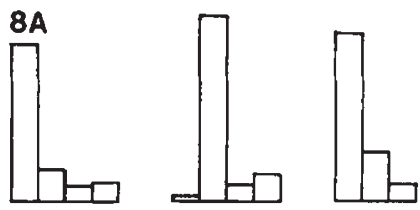

88
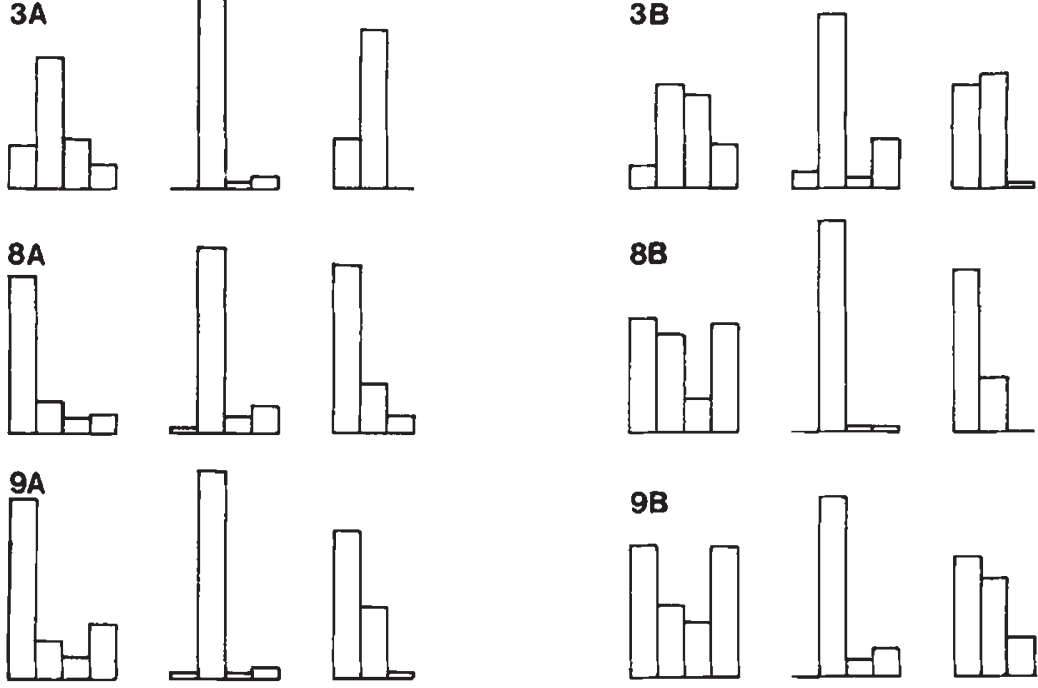

9B
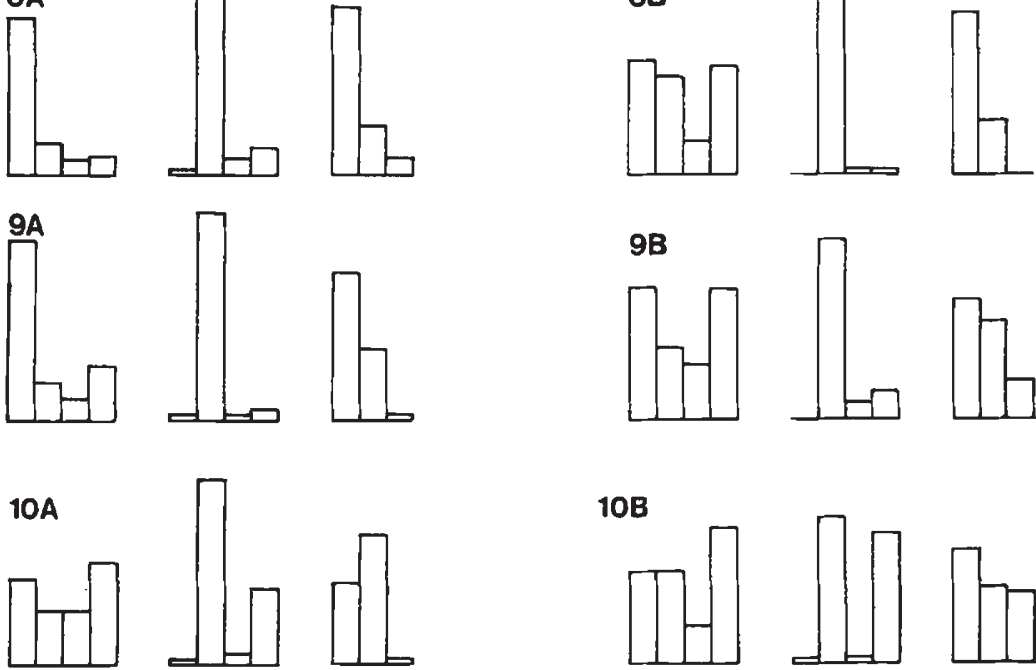

$10 B$
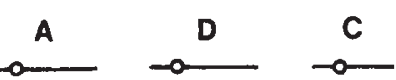

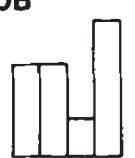

A

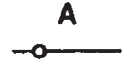

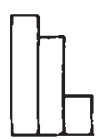

FIG. 4.-Chiasma distribution among 11 bivalent regions of Crepis capillaris for 10 plants from 5 families of population DR, to illustrate the marked variability of chiasma distribution sometimes found among families and individual plants.

data on individual families and plants. Variations in the chiasma distribution patterns of the $A$ and $C$ bivalents are particularly marked (see fig. 4), but it should be noted that these families and plants have been selected for their extreme variability and do not represent a typical sample of the variation to be found within a population.

\section{Discussion}

The role of genetical recombination in relation to the release of variability in populations and species has been extensively discussed (Mather, 1943; Darlington, 1958; Grant, 1958; McPhee and Robertson, 1970; Maynard-Smith, 1977). Much of the evidence supporting an adaptive 
advantage for recombination is of an anecdotal kind, and concerns not just the universal occurrence of recombination in eukaryotes, but also the wide variations in recombination rates (chiasma frequencies) which characterise different species of plants and animals. It has been supposed that these differences are adaptive and have evolved to suit the particular requirements and circumstances of species, as integral parts of their genetic systems (Darlington, 1958). Interspecific variations in both chiasma frequency and chiasma distribution have been extensively studied and described (e.g., John and Lewis, 1965), but there have been relatively many fewer studies of intraspecific chiasma variation. Significant levels of chiasma frequency variation have been previously reported between populations of Melandrium (Lawrence, 1963), Lolium perenne, L. italicum and Festuca pratensis (Rees and Ahmad, 1963; Rees and Dale, 1974), Chorthippus parallelus, Omocestus viridulus and Myrmeleotettix maculatus (Hewitt, 1965) Phaulacridium marginale (Westerman and Fontana, 1973), Metrioptera brachyptera (Southern, 1968), Triticum longissimum (Zarchi et. al., 1972) and Cepaea nemoralis and $C$. hortensis (Price, 1974, 1975). The genetical and evolutionary significance of inter-population differences in chiasma frequency is to a large extent unknown, with one exception (Rees and Dale, 1974) and there is certainly no ready explanation for the interpopulation chiasma frequency differences observed in this study of Crepis capillaris. Very striking and significant differences in chiasma frequency were also observed between families and within families of Crepis which indicate the presence of considerable heritable variation for chiasma frequency in these populations and high levels in heterozygosity for genes controlling chiasma frequency, as expected in an outbreeding species.

The analysis of chiasmata in Crepis capillaris according to their positions in bivalents, has permitted a number of conclusions. First, it appears that chiasmata tend to occupy characteristic positions in the bivalents of Crepis capillaris. Although this is a quantitative rather than qualitative effect, and some variation is evident, it nevertheless can be described as a type of chiasma localisation, particularly as regards the $\mathrm{C}$ and $\mathrm{D}$ bivalents which have a strong tendency to form proximal chiasmata. The variations encountered in chiasma positional distributions were evident at population, family and individual plant levels. They illustrate the fact that Crepis capillaris does not have a rigidly controlled chiasma localisation system of the type found in some other species, and this presumably reflects the segregation of genes controlling the formation of chiasmata in specific local regions. Chromosome specific controls of chiasma formation have already been identified in experimental lines of Crepis capillaris (Tease and Jones, 1976) and also in wild material (unpublished finding). The variation in chiasma distribution observed in this study points to the existence of region-specific local controls of chiasma formation in Crepis capillaris.

\section{REFERENCES}

BRANDHAM, P. E. 1969. Inversion heterozygosity and sub-chromatid exchange in Agava stricta. Chromosoma, 26, 270-286.

BROWN, L. M., AND JONES, R. N. 1976. B chromosome effects at meiosis in Crepis capillaris. Cytologia, 41, 493-506.

DARLINGTON, C. D. 1958. The Evolution of Genetic Systems. Oliver and Boyd, Edinburgh. 
FISHER, R. A., AND YATES, F. 1963. Statistical Tables for Biological, Agricultural and Medical Research. Oliver and Boyd, Edinburgh.

GRANT, V. 1958. The regulation of recombination in plants. Cold Spring Harb. Symp. Quant. Biol., 23, 337-363.

HEWITT, G. M. 1965. Population cytology of British grasshoppers. II. Annual variation in chiasma frequency. Chromosoma, 16, 579-600.

JOHN, B., AND LEWIS, K. R. 1965. The meiotic system. Protoplasmatologia VI. F1. SpringerVerlag, Vienna-New York.

LAWRENCE, C. W. 1963. Genetic studies on wild populations of Melandrium. 1. Chromosome behaviour. Heredity, 18, 135-147.

MATHER, K. 1943. Polygenic inheritance and natural selection. Biol Rev., 18, 32-64.

MAYNARD-SMITH, J. 1977. Why the genome does not congeal. Nature, 268, 693-696.

MCPHEE, C. P., AND ROBERTSON, A. R. 1970. The effect of suppressing crossing-over on the response to selection in Drosophila melanogaster. Genet. Res., 16, 1-16.

NAVASHIN, M. 1925. Morphologischen Kernstudien der Crepis-Arten in Bezug auf die Artbildung. Z. Zellforsch., 2, 98-110.

PRICE, D. J. 1974. Variation in chiasma formation in Cepaea nemoralis. Heredity, 32, 211-217.

PRICE, D. J. 1975. Chiasma frequency variation with altitude in Cepaea hortensis (Mull). Heredity, 35, 221-229.

REES, H., AND AHMAD, K. 1963. Chiasma frequencies in Lolium populations. Evolution, 17, 575-579.

REES, H., AND DALE, P. J. 1974. Chiasmata and variability in Lolium and Festuca populations. Chromosoma, 47, 335-351.

RICHARDSON, M. M. 1935. Meiosis in Crepis. I. Pachytene association and chiasma behaviour in Crepis capillaris (L) Wallr. and Crepis tectorum (L). J. Genet., 31, 101-117.

SNedecor, G. W., AND COChran, w. G., 1967. Statistical Methods, 6th ed., Iowa State University Press., Ames.

SOUTHERN, D. I. 1968. Persistent heterochromatic association in Metrioptera brachyptera. I. Variation in the frequency of multiple formation, chiasma production and chromosome morphology. Chromosoma, 25, 303-318.

TEASE, C. 1977. Ph.D. Thesis. University of Birmingham.

TEASE, C., AND JONES, G. H. 1976. Chromosome-specific control of chiasma formation in Crepis capillaris. Chromosome, 57, 33-49.

WESTERMAN, M., AND FONTANA, P. G. 1973. Polymorphisms for extra heterochromatin in Phaulacridium marginale. Heredity, 31, 223-229.

ZARCHI, Y., SIMCHEN, G., HILLEL, J., AND SCHAAP, T, 1972. Chiasmata and the breeding system in wild populations of diploid wheats. Chromosoma, 38, 77-94. 